\title{
Peranan Guru terhadap Motivasi Belajar IPS Siswa Kelas V SD Inpres 51 Kabupaten Sorong
}

\author{
Hilarius Oktavinus Koba Ora ${ }^{1}$ \& Mursalim $^{3}$
}

Program Studi PGSD, Universitas Pendidikan Muhammadiyah Sorong, Indonesia

$\bowtie$ E-mail: fhyodi@gmail.com

\begin{abstract}
Abstrak
Penelitian yang dilakukan berdasarkan hasil obsevasi yang peneliti temukan di SD Inpres 51 Kabupaten Sorong, yaitu Pengaruh Peran Guru Terhadap Motivasi Belajar IPS merupakan suatu usaha guru dalam membangun minat belajar siswa pada saat proses pembelajaran berlangsung di kelas. Penelitian ini bertujuan untuk guru membantu siswa dalam membangun motivasi belajar yang timbul dari dalam dan luar diri siswa pada mata pelajaran IPS khususnya kelas V SD Inpres 51 Kabupaten Sorong. Penelitian ini termasuk penelitian kuantitatif dengan menggunakan metode eksperimen yang merupaka hasil pengamatan dan pengukuran empiris untuk mengungkapkan fakta tentang suatu karakteristik. Subjek penelitian ini adalah siswa kelas V SD Inpres 51 Kabupaten Sorong dengan jumlah keseluruhan adalah 52 siswa. Penelitian ini menggunakan teknik obsevasi, angket, dan dokumentasi. Hasil dari penelitian yang dilakukan bahwa besarnya pengaruh peran guru dapat dilihat dari nilai R square sebesar $97,0 \%$ yang memberikan kontribusi positif terhadap peningkatan motivasi belajar siswa dengan nilai rata-rata mencapai $68,65 \%$, maka peran guru dalam memberikan movitasi belajar sangatlah penting bagi siswa pada proses pembelajaran.
\end{abstract}

Kata Kunci: Peran Guru; Motivasi Belajar; IPS.

\begin{abstract}
The study conducted based on the obsevation that researchers found at sorong district 51st, which is the teaching role of teachers on ips motivation, which is a quru attempt to build student interest during the learning process. This research is intended for teachers to assist students in building the internal and internal learning motivation Students outside of the class at ips especially the class v elementary inpres 51 district Slide. The study included quantitative work by using experimental methods of experimentation that were made by observation and empirical measurements to reveal the fact of a characteristic. The subject of this study is student The v-grade inpres 51 district sorong by the total number is 52 Student. It USES obsevation, angkets, and documentation techniques. As a result of studies conducted that the magnitude of teachers' role influences can be seen from $r$ square's $97.0 \%$ value that contributes positively to increased student learning motivation by an average of $68.65 \%$, so the teacher's role in providing learning movitation is essential to students in the learning process.
\end{abstract}

Keywords: Role of Teacher; Learning Motivation; IPS 


\section{PENDAHULUAN}

Pada dasarnya menjadi guru ideal dan profesional harus memiliki beberapa komponen, antara lain; menguasai materi pelajaran secara umum, mempunyai wawasan luas, komunikatif, menggabungkan teori dan praktik, mempunyai variasi pendekatan dengan anak didik,tidak terlalu menekan dan memaksa,humoris tapi serius. Mulyasa (Turnip et al., 2018) mengungkapkan bahwa seorang guru itu harus ahli (expert) dalam bidang yang diajarkan, memiliki rasa tanggung jawab yang tinggi, pemberi motivasi, dan memiliki rasa kesejawatan dan kode etik serta memandang tugasnya sebagai karir hidup. Oleh karena itu motivasi menjadi salah satu faktor yang dapat mempengaruhi keberhasilan pembelajaran yang dilakukan oleh guru.

Guru memiliki peranan penting dalam motivasi, karna motivasi itu akan mempengaruhi keberhasilan dalam pembelajaran yang telah di tetapkan. Sebab dengan Dorongan motivasi oleh guru dalam belajar maka akan membangkitkan semangat belajar siswa dan akan berdampak pada hasil atau prestasi belajar peserta didik terlebih khusus tingkah laku peserta didik tersebut. Biggs dan Tefler (Ghullam Hamdu, 2011) mengungkapkan motivasi belajar siswa dapat menjadi lemah. Lemahnya motivasi atau tidak adanya motivasi akan melemahkan kegiatan belajar, sehingga mutu belajar peserta didik menjadi menurun. Semakin sering guru memberikan motivasi kepada siswa maka siswa akan termotivasi dalam belajar. Siswa yang bermotivasi tinggi dalam belajar, akan memperoleh hasil belajar yang tinggi pula.

Artinya semakin tinggi motivasinya, semakin intensitas usaha dan upaya yang dilakukan, maka semakin tinggi prestasi belajar yang diperolehnya.

Dalam hal ini, peneliti ingin meneliti bagaimana peran guru dalam memberikan motivasi belajar IPS pada siswa. Bukan hanya menggunakan metode yang sudah biasa di gunakan tetapi di sini peneliti ingin mengetahui bagai mana kemampuan guru dalam memberikan motivasi belajar siswa. Dengan akademik yang tinggi, guru dapat menggunakan berbagai macam strategi dan metode pembelajaran baru, sehingga guru dapat memberikan warna atau sesuatu yang baru kepada siswa. Peran guru dalam pemberian motivasi belajar sangatlah diperlukan. hal ini dapat menjadi acuan sebagai pendorong usaha dan pencapaian prestasi atau semangat belajar bagi peserta didik Terutama pada proses pembelajaran IPS yang telah ditetapkan agar dapat tercapai.

Namun berdasarkan Obsevasi pada saat magang 2 pada tanggal 22 Februari 2019, yang peneliti temukan di kabupaten Sorong khususnya di SD Inpres 51 Kabupaten Sorong diperoleh bahwa masih ada guru yang belum sepenuhnya memberikan motivasi terhadap peserta didik di dalam kegiatan belajar, terutama pada proses belajar IPS. Hal tersebut berdampak pada semangat belajar peserta didik menjadi rendah, keaktifan siswa di dalam kelas sangat kurang, proses pembelajaran yang monoton, peserta didik tidak ada perhatian terhadap guru, sering berbuat gaduh di dalam kelas. Oleh karena itu dorongan dalam bentuk motivasi belajar merupakan salah satu hal yang perlu dibangkitkan dalam upaya pembelajaran di sekolah. Begitu juga dengan tindakan peran gurunya dalam proses pembelajaran yang peneliti temukan yaitu strategi pembelajaran yang kurang begitu menarik, tidak ada pemberian penghargaan berupa reward (pujian-pujian kepada peserta didik), cara mengajar guru yang monoton 
sehingga rangsangan yang berupa stimulus tidak diperlihakan atau di berikan kepada peserta didik. tetapi dalam hal ini masih hipotesis peneliti, karena peneliti beranggapan motivasi belajar siswa rendah disebabkan oleh peran gurunya.

Terkait dengan masalah yang peneliti temukan di SD Inpres 51 Kabupaten Sorong bahwa guru harus bisa memberikan motivasi belajar kepada peserta didik agar proses pembelajaran dapat tercapai sesuai dengan keinginan. Sehingga dengan penelitian ini dapat memberikan perubahan dalam proses belajar mengajar.

Permasalahan di atas, terkait dengan pentingnya peran guru dalam pemberian motivasi belajar IPS maka peneliti tertarik mengangkat permasalahan diatas yaitu peran guru dan motivasi belajar siswa yang ingin diteliti dengan judul Pengaruh peran guru terhadap motivasi belajar IPS siswa kelas V SD Inpres 51 Kabupaten Sorong. Tujuan dari penelitian ini adalah untuk mengetahui Pengaruh Peran Guru terhadap Motivasi Belajar Siswa IPS Kelas V SD Inpres 51 Kabupaten Sorong. (Fadil Yudia Fauzi, Ismail Arianto, 2013) seorang guru harus menjadi seorang pengasuh bagi peserta didik, menjadi panutan dan teladan untuk dicontoh oleh peserta didik, guru pula harus menjadi pembimbing untuk membimbing anak didiknya yang memiliki integritas dan kedisiplanan dalam kehidupan sehari-hari. (Krisno Prastyo Wibowo, 2015).

Pembelajaran IPS merupakan bagian dari fungsi sekolah untuk memelihara martabat masyarakat melalui penanaman nilai. Fokus pembelajaran IPS adalah nilai kemanusiaan dalam suatu pranata dan kontribusi antara manusia dengan manusia, maupun dengan lingkungannya. (Sulihin B. Sjukurn, 2012) motivasi adalah proses internal yang mengaktifkan, menuntun, dan mempertahankan perilaku dari waktu ke waktu, (Amin Kiswoyono, 2011) Motivasi belajar merupakan keseluruhan daya penggerak di dalam diri siswa yang menimbulkan kegiatan belajar, yang menjamin kelangsungan dari kegiatan belajar dan yang memberikan arah pada kegiatan belajar, sehingga tujuan yang dikehendaki dapat tercapai.

\section{METODE PENELITIAN}

Penelitian ini termasuk jenis penelitian kuantitatif dengan metode eksperimen. Penelitian ini dilaksanakan di SD Inpres 51 Kabupaten Sorong kelas V. populasi dalam penelitian ini adalah seluruh siswa kelas $\mathrm{V}$ SD Inpres 51 Kabupaten Sorong yang berjumlah 52 siswa. . Dalam penelitian ini sampel yang akan diambil adalah siswa kelas V B SD Inpres 51 Kabupaten Sorong yang berjumlah 21 orang yang terdiri dari 14 siswa laki-laki dan 7 siswa perempuan. Instrument dalam penelitian ini berupa angket dan dokumentasi.

\section{HASIL DAN PEMBAHASAN}

Penelitian ini dilaksanakan pada siswa kelas V B yang berjumlah 21 orang. Penelitian ini dilakukan dengan memberikan angket kepada peserta didik di kelas V B.

Penelitian ini menggunakan intrumen penelitian berupa angket berjumlah 20 item pernyataan yang berkaitan peran guru serta 20 item angket motivasi belajar siswa. Sebelum soal diberikan kepada siswa di sekolah, terlebih dahulu dikonsultasikan dengan satu professional Judgment dosen PGSD Unimuda Sorong dengan cara dimintai pendapat tentang instrument yang telah disusun oleh peneliti. Keputusan Ahli tersebut memutuskan bahwa instrument angket motivasi belajar yang telah dibuat tersebut layak digunakan dengan catatan revisi. 
Pengujian reliabilitas instrumen dalam penelitian ini menggunakan rumus Cronbach's Alpha dengan menggunakan Program IBM SPSS Statistics Versi 21.0, dengan Nilai $r_{\text {tabel }}$ untuk $\mathrm{N}=21$ pada signifikansi $5 \%$, ditemukan nilai $r_{\text {tabel }}$ sebesar 0,817 untuk angket motivasi belajar dan rtabel untuk peran guru sebesar 0,810 .

Uji normalitas digunakan untuk mengetahui apakah data yang diperoleh dari masing-masing variabel berdistribusi normal atau tidak. Uji normalitas ini dilakukan terhadap skor angket peran guru dan angket motivasi belajar siswa. Berikut ini rangkuman hasil uji normalitas:

Tabel 1. Uji Normalitas data

\begin{tabular}{llllll} 
ANOVA $^{\mathbf{a}}$ & & & \\
\hline Model & $\begin{array}{l}\text { Sum of } \\
\text { Square } \\
\end{array}$ & $\mathrm{df}$ & $\begin{array}{l}\text { Mean } \\
\text { Square }\end{array}$ & $\mathrm{F}$ & Sig. \\
& $\mathrm{s}$ & & & \\
\hline Regressio & 868.44 & 1 & 868.443 & 622.4 & $.000^{\mathrm{D}}$ \\
$\mathrm{n}$ & 3 & & & 40 & \\
Residual & 26.509 & 19 & 1.395 & & \\
Total & 894.95 & 20 & & & \\
a. Dependent Variable: Motivasi Belajar & \\
b. Predictors: (Constant), Peran Guru &
\end{tabular}

Kriteria yang digunakan adalah jika hasil sig $>$ 0,05 maka distribusi frekuensi tersebut normal, sebaliknya jika hasil sig $<0,05$ maka distribusi frekuensi tidak normal. Seluruh proses perhitungan dilakukan dengan bantuan program SPSS V21.0 for windows.

\section{Uji Hipotesis}

\section{Analisis Regresi Sederhana}

Adapun hasil perhitungan uji statistik regresi linier sederhana yang dihitung dengan Nilai $\mathrm{R}$ yang merupakan simbol dari koefisien. Pada tabel 2 nilai korelasi adalah 0,985 . Nilai ini dapat diinterpretasikan bahwa hubungan kedua variabel penelitian berada pada kategori sangat cukup. Melalui tabel diatas juga diperoleh nilai $\mathrm{R}$ Square atau koefisien determinasi (KD) yang menunjukkan seberapa bagus model regresi yang dibentuk oleh interaksi variabel bebas dan variabel terikat. Nilai KD yang diperoleh adalah 97,0\%. Sehingga dapat ditafsirkan bahwa variabel bebas $\mathrm{X}$ memiliki pengaruh kontribusi sebesar $97,0 \%$ terhadap variabel Y.

Tabel 2. Uji normalitas

One-Sample Kolmogorov-Smirnov Test

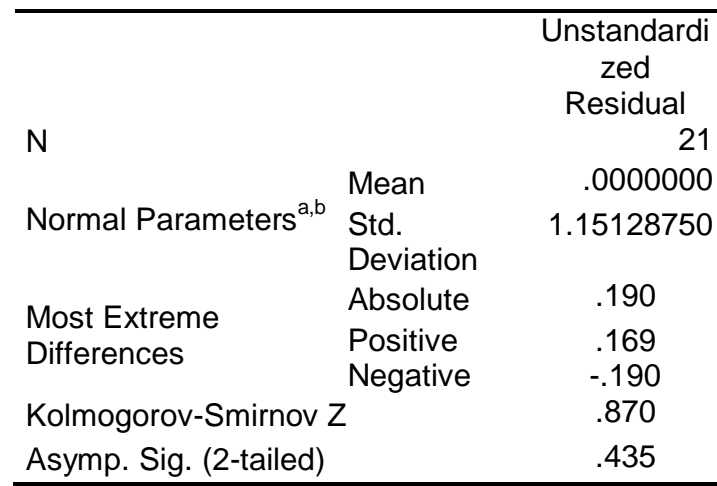

Adapun hasil perhitungan uji statistik regresi linier sederhana yang dihitung dengan menggunakan aplikasi IBM SPSS Statistics Versi 21.0 :

Tabel 3. Hasil Output SPSS Uji Regresi Linier Sederhana

\begin{tabular}{|c|c|c|c|}
\hline \multicolumn{4}{|c|}{ Model Summary } \\
\hline \multirow[t]{3}{*}{$\mathrm{R}$} & R Square & Adjusted & Std. Error of the \\
\hline & & $\mathrm{R}$ & Estimate \\
\hline & & Square & \\
\hline $.985^{\mathrm{a}}$ & .970 & .969 & 1.18120 \\
\hline
\end{tabular}

Nilai $R$ yang merupakan simbol dari koefisien. Pada tabel di atas nilai korelasi adalah 0,985. Nilai ini dapat diinterpretasikan bahwa hubungan kedua variabel penelitian berada pada kategori sangat cukup. Melalui tabel diatas juga diperoleh nilai $\mathrm{R}$ Square atau koefisien determinasi (KD) yang menunjukkan seberapa bagus model regresi yang dibentuk oleh interaksi variabel bebas dan variabel terikat. Nilai KD yang diperoleh adalah $97,0 \%$. Sehingga dapat ditafsirkan bahwa variabel bebas $\mathrm{X}$ memiliki pengaruh kontribusi sebesar 97,0\% terhadap variabel Y.

Tabel 3 pada uji signifikansi di atas, 

$\begin{array}{lll}\text { digunakan untuk menentukan } & \text { taraf } \\ \text { signifikansi atau lineritas dari regresi. }\end{array}$ Kriteria dapat ditentukan berdasarkan uji nilai signifikansi (sig), dengan ketentuan jika nilai sig $<0,05$. Berdasarkan tabel diatas diperoleh nilai sig. $=0,00$ berarti sig $<$ dari kriteria signifikan $(0,05)$ dengan demikian model persamaan regresi berdasarkan data penelitian adalah signifikan, atau model persamaan regresi memenuhi kriteria.

Hasil penghitungan koefisien regresi sederhana diatas memperlihatkan nilai koefisien konstanta adalah sebesar 1.009 koefisien variabel bebas (X) adalah sebesar 0,414 . Sehingga diperoleh persamaan regresi $\mathrm{Y}=1.009+0,414 \mathrm{X}$.

Berdasarkan persamaan diatas diketahui nilai konstantanya sebesar 1.009. secara matematis, nilai konstanta ini menyatakan bahwa pada saat peran guru 0 , maka motivasi belajar memiliki nilai 1.009 . lebih jelasnya dapat dilihat pada tabel 4 berikut;

Tabel 4. Koefisien Angket motivasi

Coefficients $^{a}$

\begin{tabular}{lrrrrr}
\hline \multicolumn{2}{c}{$\begin{array}{c}\text { Unstandardized } \\
\text { Coefficients }\end{array}$} & \multicolumn{2}{c}{$\begin{array}{c}\text { Standardized } \\
\text { Coefficients }\end{array}$} & & Sig. \\
\cline { 1 - 3 } B & Std. Error & Beta & & \\
\cline { 1 - 3 } .414 & 2.650 & & .156 & .878 \\
1.009 & .040 & .985 & 24.949 & .000 \\
\hline
\end{tabular}

a. Dependent Variable: Motivasi Belajar

Selanjutnya nilai positif $(0,414)$ yang terdapat pada koefisien regresi variabel bebas (peran guru) menggambarkan bahwa arah hubungan antara variabel bebas (peran guru) dengan variabel terikat (motivasi belajar) adalah searah, dimana setiap kenaikan satu satuan variabel peran guru akan akan menyebabkan kenaikan motivasi belajar 0,414

Hasil korelasi peran guru dan motivasi belajar siswa menunjukkan hasil yang signifikan hal ini ditunjukkan pada tabel 5 berikut;

Tabel 5. Uji Signifikansi korelasi

\begin{tabular}{|c|c|c|c|}
\hline \multicolumn{4}{|c|}{ Correlations } \\
\hline & & $\begin{array}{l}\text { Peran } \\
\text { Guru }\end{array}$ & $\begin{array}{l}\text { Motivasi } \\
\text { Belajar }\end{array}$ \\
\hline \multirow{3}{*}{$\begin{array}{l}\text { Peran } \\
\text { Guru }\end{array}$} & Pearson Correlation & 1 & $.985^{\prime \prime}$ \\
\hline & Sig. (2-tailed) & & .000 \\
\hline & $\mathrm{N}$ & 21 & 21 \\
\hline \multirow{3}{*}{$\begin{array}{l}\text { Motivasi } \\
\text { Belajar }\end{array}$} & Pearson Correlation & $.985^{\pi \pi}$ & 1 \\
\hline & Sig. (2-tailed) & .000 & \\
\hline & $\mathrm{N}$ & 21 & 21 \\
\hline
\end{tabular}

responden sebanyak 21 dihasilkan nilai kolerasi sebesar 0,985. Untuk melakukan interpretasi kekuatan hubungan antara dua variabel dilakukan dengan melihat angka koefisien kolerasi hasil perhitungan dengan menggunakan interpretasi nilai $r$ adalah sebagai berikut:
\ 0 : Tidak ada korelasi antara dua variabel
$>0-0,25 \quad$ : Korelasi sangat lemah
$>0,25-0,5 \quad$ : Korelasi cukup
$>0,5-0,75 \quad$ : Korelasi kuat
$>0,75-0,99$ : Korelasi sangat kuat
1
: Korelasi sempurna

Catatan:

Tanda (+) atau (-) hanya menunjukkan arah hubungan.

Nilai $r$ terbesar adalah +1 dan $r$ terkecil adalah -1 .

$\square \mathrm{r}=+1$ menunjukkan hubungan positif sempurna, sedangkan $r=-1$ menunjukkan hubungan negatif sempurna.

Dari data di atas dapat diambil kesimpulan bahwa antara variabel Peran Guru (X) dengan variabel Motivasi Belajar (Y) mempunyai pengaruh yang sangat kuat karena mempunyai nilai korelasi sebesar 0,985 .

\section{Hasil Uji t}

Perumusan Hipotesis

Ho : Tidak Ada Pengaruh Peran Guru terhadap Motivasi Belajar IPS Siswa Kelas V SD Inpres 51 Kabupaten Sorong. 
Ha : Ada Pengaruh Peran Guru terhadap Motivasi Belajar IPS Siswa Kelas V SD Inpres 51 Kabupaten Sorong.

\section{Penetapan Kriteria}

Besarnya nilai t tabel untuk taraf signifikan $5 \% \mathrm{db}=19(\mathrm{db}=\mathrm{N}-2$ untuk $\mathrm{N}=21)$ yaitu 2,093 .

\section{Hasil t hitung}

Hasil thitung diperoleh dengan menggunakan SPSS 21.0 for windows yaitu sebesar 24,949.

\section{Pengambilan Keputusan}

Jika thitung lebih besar dari ttabel maka Ha diterima dan Ho ditolak. Dari hasil perhitungan thitung sebesar 24,949 di atas dibandingkan dengan ttabel $(\mathrm{db}=19)$ yaitu 2,093 taraf signifikan 5\%, jadi thitung > ttabel maka Ha diterima dan Ho ditolak. Dengan kata lain menolak hipotesis nol (Ho) dan menerima hipotesis alternatif (Ha) untuk pengujian kedua variable.

Tabel 6. Koefisien determinen

\begin{tabular}{|c|c|c|c|c|}
\hline \multicolumn{5}{|c|}{ Model Summary } \\
\hline \multirow[t]{2}{*}{ Model } & $\mathrm{R}$ & $\mathrm{R}$ & Adjusted & Std. Error of \\
\hline & & Square & R Square & the Estimate \\
\hline 1 & $.985^{\mathrm{a}}$ & .970 & .969 & 1.18120 \\
\hline
\end{tabular}

Setelah $r_{\text {hitung }}$ diketahui sebesar 0,985 maka selanjutnya untuk mengetahui seberapa besar pengaruh variabel $\mathrm{X}$ terhadap variabel $\mathrm{Y}$ dengan menggunakan koefisien determinan $\mathrm{R}^{2}$ yang dinyatakan dalam persentase.

$$
\begin{aligned}
& \text { Hasilnya sebagai berikut: } \\
& \begin{aligned}
\mathrm{R}^{2} & =(0,985)^{2} \times 100 \% \\
& =97,022 \times 100 \% \\
& =97,0 \% \text { dibulatkan }(97 \%)
\end{aligned}
\end{aligned}
$$

Dari hasil perhitungan di atas maka dapat disimpulkan bahwa ada pengaruh variabel $\mathrm{X}$ terhadap $\mathrm{Y}$ sebesar $97 \%$ dan selebihnya yang $3 \%$ dipengaruhi oleh faktor lain.

Dari hasil penelitian yang dilakukan menggunakan angket Peran Guru dan
Motivasi Belajar pada Siswa Kelas V SD Inpres 51 Kabupaten Sorong. Dilakukan beberapa uji untuk mendapatkan data hasil yang diinginkan uji yang dilakukan yaitu, Uji Validitas dan Uji Reliabilitas, uji ini dilakukan untuk mengetahui valid dan reliabel angket yang digunakan agar hasil yang didapat dari uji keduanya dinyatakan valid dan reliabel. Sama halnya dengan angket peran guru, hasil angket motivasi belajar menunjukkan motivasi belajar yang cukup tinggi karena peran guru sudah mulai memberikan motivasi yang tinggi pula kepada siswa SD Inpres 51 Kabupaten Sorong.

Penelitian ini menunjukan bahwa guru berperan penting dalam membangun motivasi belajar siswa. Dari total sampel yang diambil dapat dilihat bahwa jumlah skor peran guru 68,5. Angka tersebut menunjukan kualitas peran guru cukup baik, sedangkan untuk motivasi belajar memperoleh total skor 68,65 dengan kategori cukup baik. Dapat dilihat bahwa peran guru mempunyai pengaruh terhadap motivasi belajar siswa kelas $\mathrm{V}$ SD Inpres 51 Kabupaten Sorong. Hal tersebut bisa meningkat apabila peran guru mampu memberikan motivasi secara baik dan terus menerus kepada siswa.

Dari perhitungan koefisien korelasi didapat hasil $r$ sebesar 0,985 angka ini cenderung mendekati 1. Berdasarakan kriteria yang dijelaskan pada bab sebelumnya, dapat disimpulkan bahwa peran guru dan motivasi belajar siswa memiliki korelasi sangat tinggi. Nilai koefisien determinasi dalam penelitian ini adalah $\mathrm{D}=$ 0,970 koefisien determinasi menunjukan 97\% motivasi belajar siswa dipengaruhi oleh peran guru. Dari hasil perhitungan diperoleh nilai koefisien pendua intersap (a) sebesar 1,009 dan nilai koefisien intersap regresi (b) 
0,414 sehingga persamaan regresi linier adalah $\mathrm{Y}=1.009+0,414 \mathrm{X}$. nilai penduga intersap dan koefisien intersap didapat dari panduan skor peran guru dan motivasi belajar siswa kelas V. Persamaan diatas menunjukan adanya pengaruh peran guru terhadap motivasi belajar siswa.

Dalam penelitian yang telah dilakukan, didapat hasil $t_{\text {tabel }}$ sebesar 2,093 pada taraf $5 \%$. Disini terlihat hasil thitung $=24,949$ yang lebih besar daripada tabel sehingga peran guru terhadap motivasi belajar siswa kelas V SD Inpres 51 Kabupaten Sorong berada pada taraf signifikan.

\section{Menurut Sardiman}

mengemukakan tiga fungsi motivasi yaitu: 1) mendorong timbulnya tingkah laku atau perbuatan. Tanpa motivasi tidak akan timbul suatu perbuatan. Motivasi dalam hal ini merupakan motor penggerak dari setiap kegiatan yang akan dikerjakan; 2) motivasi berfungsi sebagai pengarah. Artinya motivasi mengarahkan perubahan untuk mencapai yang diinginkan. Dengan demikian, motivasi dapat memberikan arah dan kegiatan yang harus dikerjakan sesuai dengan rumusan tujuannya; 3) motivasi berfungsi sebagai penggerak. Artinya menggerakkan tingkah laku seseorang. Selain itu motivasi belajar berfungsi sebagai pendorong usaha dan pencapaian prestasi.

\section{KESIMPULAN}

Berdasarkan hasil pengamatan dan analisis terhadap hasil penelitian, maka dapat diambil kesimpulan bahwa variabel $\mathrm{X}$ terdapat pengaruh yang signifikan terhadap variabel Y. Dari hasil pengujian hipotesis tersebut terbukti bahwa "Ada Pengaruh Yang Signifikan Antara Peran Guru terhadap Motivasi Belajar IPS Siswa Kelas V SD Inpres 51 Kabupaten Sorong”.

Hal ini dibuktikan dari hasil penelitian yaitu 33\% siswa yang sudah mendapatkan motivasi baik dan 67\% siswa SD Inpres 51 Kabupaten Sorong sudah mendapatkan motivasi yang cukup baik dari guru sehingga memacu semangat untuk terus belajar mata pelajaran IPS.

\section{DAFTAR RUJUKAN}

Alwi, E. (2002). Penggunaan Peta dan Globe untuk Meningkatkan Prestasi Belajar IPS di Sekolah Dasar, (1), 62-68.

Amin Kiswoyono. (2011). Pengaruh Motivasi Belajar Dan Kegiatan Belajar Siswa Terhadap Kecakapan Hidup Siswa, (1), 120-126.

Anggriani, F. (2014). Penerapan Metode Pembelajaran Berbasis Masalah Untuk Meningkatkan Hasil Belajar Siswa Pada Mata Pelajaran IPS Kelas IV SD Inpres 1 Margapura, 4(5), 162-176.

Aprida Pane. (2017). BelajarDan Pembelajaran Aprida Pane Muhammad Darwis Dasopang. Fitrah, 03(2), 333-352.

Aprilianti, E. (2017). Pengaruh Penerapan Model Pembelajaran Discovery Learning Terhadap Hasil Belajar Tematik Siswa Kelas V Sekolah Dasar Negeri 2 Labuhan Ratu Bandar Lampung.

Arikunto, S. (2010). Prosedur Penelitian suatu pendekatan praktik.

Ayu Febriana. (2011). Penerapan Model Pembelajaran Kooperatif Tipe Make A Match Untuk Meningkatkan Kualitas Pembelajaran IPS Siswa KelasV SDN Kalibangteng Kidul 01 Kota Semarang, 1(2), 151-161.

Dasem, A. A., Laka, B. M., \& Niwele, A. (2018). peranan guru dalam proses pembelajaran bahasa indonesia di SD inpres komboi kabupaten biak numfor, 2(2), 126-136.

Dessy Anggraeni. (2011). Peningkatan Kualitas Pembelajaran IPS Melalui Model Pembelajaran Kooperatif Tipe Course Reiview Horay Pada Siswa Kelas IV SD Negeri Sekaran 01 Semarang.

Erlisnawati, H. M. (2015). Implementasi Model Pembelajaran Berdasarkan Masalah Untuk Meningkatkan Hasil Belajar IPS Siswa Kelas IV SDN 169 Pekanbaru, 4(2), 87-97.

Fadil Yudia Fauzi, Ismail Arianto, E. S. (2013). Peran Guru Pendidikan Pancasila Dan Kewarganegaraan Dalam Upaya 
Pembentukan Karakter Peserta Didik, 1(2).

Ghullam Hamdu, L. A. (2011). Pengaruh Motivasi Belajar Siswa Terhadap Prestasi Belajar IPA Di Sekolah Dasar, 12(1), 8186. 10.1002/anie. 200802338 https://doi.org/DOI

Ilahi, N. W., Imaniyati, N., \& Setiabudhi. (2016). Peran guru sebagai manajer dalam meningkatkan efektivitas proses pembelajaran ( The role of teacher as manager to increase effective learning process ), 1(1), 99-108.

Ismail, M. I. (2010). Kinerja Dan Kompetensi Guru Dalam Pembelajaran, 13(1), 44-63.

Keke T. Aritonang. (2008). Minat dan Motivasi dalam Meningkatkan Hasil Belajar Siswa, (10), 11-21.

Khasanah, U. (2018). Peran Guru IPS Dalam Meningkatkan Motivasi Belajar Siswa Mata Pelajaran Ilmu Pengetahuan Sosial Kelas VII Unggulan DiMTS Roudlotun Nasyi'in Mojokerto.

Krisno Prastyo Wibowo, M. (2015). Penerapan Model Make A Match Berbantuan Media Untuk Meningkatkan Motivasi Dan Hasil Belajar IPS, 2(2), 158-169.

Kusumastut, A. (2013). Peningkatan Kualitas Pembelajaran IPS Melalui Model Thinkpairshare Berbantuan Vidio Pembelajaran Pada Siswa Kelas V A SDN Bojong Salaman 02 Kota Semarang.

Mahalli. (2016). BAB II Kerangka Teori. Digilib UIN Surabaya, 21-34.

Masyuni weka hery setiawan. (2017). Peran Guru PAI Dalam Meningkatkan Motivasi Belajar Siswa SD Negeri 134 Klumpang Kecamatan Bontotiro Kabupaten Bulukumba.

Muh. Yusuf Mappeasse. (2009). Pengaruh Cara Dan Motivasi Belajar Terhadap Hasil Belajar Programmable Logic Controller ( PLC ) Siswa Kelas III Jurusan Listrik SMK
Negeri 5 Makassar, 1(2), 1-6.

Mutia Aprianti. (2015). Peranan Guru Dalam Pembelajaran Terhadap Hasil Belajar Di SMA Negeri 1 Makasar.

Rina Astuti, Widha Sunarno, S. S. (2012). Pembelajaran ipa dengan pendekatan keterampilan proses sains menggunakan metode eksperimen bebas termodifikasi dan eksperimen terbimbing ditinjau dari sikap ilmiah dan motivasi belajar siswa, 1(1).

Roida, E, F, S. (2013). Pengaruh Minat dan Kebiasaan Belajar Siswa Terhadap Prestasi Belajar Matematika. Jurnal Formatif, 2(2), 122-131.

Saragih, A. H. (2008). Kompetensi Minimal Seorang Guru.

Sardiman A.M. (2016). Interaksi dan Motivasi Belajar Mengajar. Jakarta: PT Raja Grafindo Persada.

Siti Maesaroh. (2013). Peranan Metode Pembelajaran Terhadap Minat Dan Prestasi Belajar Pendidikan Agama Islam, 1(1), 150-168.

Soraya dwi kartika. (2016). Peran Guru Dalam Memotivasi Belajar Siswa Pada Mata Pelajaran IPS Terpadu Di SMP PGRI 2 Ciledug.

Sugiyono. (2018). Metode Penelitian Pendidikan. Jurnal Promosi.

Sulihin B. Sjukurn. (2012). pengaruh blended learning terhadap motivasi belajar dan hasil belajar siswa tingkat SMK, 2(3), 368-378.

Turnip, H., Situmorang, B., \& Matondang, Z. (2018). Pengaruh Kecerdasan Emosional , Persepsi Guru Tentang Komunikasi Kompensasi Interpersonal Terhadap Kepala Guru TK Komitmen Afektif Kecamatan Medan Perjuangan, 4(2), 39-54.

Yesi Budiarti. (2015). Pengembangan Kemampuan Kreativitas Dalam Pembelajaran IPS, 3(1), 61-72. 